\title{
Pemidanaan Sebagai Ultimum Remidium Dalam Memberikan Perlindungan Hukum Terhadap Hak-Hak Konsumen Pada Suatu Transaksi Elektronik
}

\author{
Ronny Indrawan \\ Universitas Katolik Darma Cendika ,Email: indrawan_ronny@yahoo.com
}

\begin{abstract}
This paper discusses the issue concerning the legal protection of consumer rights in transaction activity which at present its development has started to use technology based on computer and telecommunication in cyberspace. This paper argues that in today's era there are often problems related to electronic transactions, especially with regard to consumer rights. Therefore, in providing legal protection against the fulfillment of consumer rights, the study from the perspective of criminal law becomes very important. Furthermore, this paper explains, among other things, the rights of consumers to be protected by criminal law, criminal forms in electronic transactions, the modus operandi of criminals, and applicable criminal sanctions for the perpetrators. This paper aims to examine the role of punishment as a last resort in protecting consumer rights from electronic transaction crimes. The method used in this paper is the Case Approach and Statute Approach. This writing concludes that there is a need for severe criminal sanctions as ultimum remidium that is able to provide a deterrent effect for the perpetrators as well as more specific regulations in criminal law specifically related to locus and tempus delictie (place and time of the crime) in electronic transaction crimes, proving electronic and social media as criminal law subjects.
\end{abstract}

Keywords: Consumer Protection, Electronic Transactions, Criminal law

\begin{abstract}
Abstrak
Tulisan ini membahas isu yang berkaitan dengan perlindungan hukum terhadap hak-hak konsumen dalam aktivitas transaksi yang pada masa sekarang perkembangannya sudah mulai menggunakan teknologi yang berbasis komputer maupun telekomunikasi di dunia maya. Tulisan ini berargumen bahwa pada era saat ini seringkali terjadi permasalahan yang terkait dengan transaksi elektronik, terutama menyangkut hak-hak konsumen. Oleh karena itu, dalam memberikan perlindungan hukum terhadap pemenuhan hak-hak konsumen, kajian dari sudut pandang hukum pidana menjadi sangat penting. Lebih lanjut, tulisan ini menjelaskan antara lain tentang hak-hak konsumen yang harus dilindungi oleh hukum pidana, bentuk-bentuk kejahatan dalam transaksi elektronik, modus operandi dari para pelaku tindak pidana, serta sanksi pidana yang bisa diterapkan bagi para pelakunya.Tulisan ini bertujuan untuk mengkaji peran pemidanaan sebagai upaya terakhir dalam melindungi hak-hak konsumen dari kejahatan transaksi elektronik. Adapun Metode yang digunakan dalam penulisan ini adalah metode pendekatan Kasus (Case Approach) dan pendekatan Undang-Undang (Statute Approach). Penulisan ini menghasilkan kesimpulan bahwa diperlukan adanya sanksi pidana berat sebagai ultimum remidium yang mampu memberikan efek jera bagi pelakunya serta diperlukan adanya pengaturan lebih spesifik dalam aturan hukum pidana khususnya terkait locus dan tempus delictie (tempat dan waktu dilakukannya tindak pidana) dalam kejahatan transaksi elektronik, pembuktian elektronik dan media sosial sebagai subjek hukum pidana.
\end{abstract}




\section{Pendahuluan}

Pada era dimana teknologi informasi dan komunikasi menjadi kekuatan utama serta kebutuhan bagi setiap manusia, maka pola berkomunikasi manusia yang dahulu bersifat konvensional, saat ini telah bertransformasi menjadi pola komunikasi yang menggunakan media teknologi dan alat komunikasi sebagai perantara dalam berkomunikasi. Hal tersebut saat ini dipandang sebagai cara yang paling efektif dalam berkomunikasi karena dengan semakin canggihnya teknologi informasi dan komunikasi, maka komunikasi tidak lagi dibatasi oleh jarak dan waktu.

Teknologi komunikasi yang semakin canggih tentunya mempermudah kehidupan manusia dalam berbagai aspek, salah satunya dalam aspek perdagangan yang dahulunya bersifat konvensional, sekarang telah bertransformasi menjadi perdagangan di dunia maya. Hal ini dipandang oleh banyak orang sebagai cara yang paling efektif dalam bertransaksi, namun di sisi lain ternyata dampak positif yang diberikan oleh teknologi komunikasi tersebut justru seringkali dimanfaatkan oleh orang-orang tertentu untuk melakukan kejahatan-kejahatan yang dulunya sulit dilakukan sebelum berkembangnya teknologi informasi dan komunikasi.

Kejahatan-kejahatan dalam transaksi elektronik tersebut dalam perkembangannya dewasa ini, juga mulai terjadi secara masif dan bermunculan berbagai modus operandi baru yang pada akhirnya merugikan hak-hak dari konsumen. Pemberantasan kejahatan-kejahatan dalam aktivitas transaksi elektronik perlu dikaji secara komprehensif dari sudut pandang hukum pidana.

\section{Metode Penelitian}

Tulisan ini menggunakan metode penelitian hukum normatif karena fokus kajian berangkat dari kekaburan norma ${ }^{1}$, menggunakan pendekatan: Pendekatan Kasus (Case Approach) dan Pendekatan Undang-Undang (Statute Approach). Tehnik penelusuran bahan hukum menggunakan tehnik studi dokumen, serta analisis kajian menggunakan analisis kualitatif.

\section{Hasil Dan Pembahasan}

3.1 Pemidanaan Sebagai Ultimum Remidium Dalam Memberikan Perlindungan Hukum Terhadap Hak-Hak Konsumen Pada Suatu Transaksi Elektronik

Hukum pidana pada hakekatnya adalah hukum sanksi, yaitu hukum yang memberikan sanksi atau suatu penderitaan bagi pelaku tindak pidana. Sifat hukum pidana yang dapat memberikan sanksi bagi pelaku tindak pidana diperlukan tidak hanya untuk menghukum pelaku tindak pidana, namun juga untuk melindungi hakhak korban.

Pada konteks aktivitas bisnis khususnya perdagangan, maka akan timbul hak dan kewajiban antara penjual dan pembeli yang tentunya harus dipenuhi oleh para

1 Lihat Diantha, I. M. P. (2016). Metodologi Penelitian Hukum Normatif dalam Justifikasi Teori Hukum. Prenada Media. h. 12. 
pihak. Pada dewasa ini, dunia perdagangan konvensional secara perlahan-lahan mulai bergeser menuju ke arah perdagangan di dunia maya atau yang saat ini lebih dikenal dengan sebutan perdagangan jual beli "online". Jual beli online pada dasarnya merupakan aktivitas jual beli yang menggunakan perantara elektronik dengan cara memanfaatkan kecanggihan teknologi dan informasi elektronik yang semakin hari semakin berkembang pesat dan digunakan oleh orang dari berbagai belahan dunia, sehingga dengan demikian maka aktivitas perdagangan konvensional secara face to face antara pembeli dan penjual mulai ditinggalkan. Pada kenyataan yang terjadi di lapangan, aktivitas jual beli di dunia maya seringkali menimbulkan permasalahan hukum, terutama berkaitan dengan hak-hak konsumen yang seringkali diabaikan oleh si penjual. Pasal 1 UUPK 1999 mengatur mengenai perlindungan konsumen. Namun, pada kenyataannya UUPK 1999 belum sepenuhnya mengatur mengenai transaksi elektronik, hanya beberapa pasal saja yang dapat dipergunakan dalam transaksi elektronik. $^{2}$

Terkait dengan isu tersebut, maka perlu dikaji secara lebih mendalam bagaimana hukum pidana yang berfungsi untuk melindungi masyarakat, dapat berperan dalam memberikan perlindungan terhadap hak-hak konsumen pada suatu transaksi elektronik. Perlu diketahui bahwa secara terminologi mengenai apakah yang dimaksud dengan transaksi elektronik, dalam hal ini rumusan Kitab Undang-Undang Hukum Pidana (KUHP) sebenarnya sudah memasukkan istilah elektronik yang dimaknai sebagai benda yang tidak berwujud. Menurut hukum Pidana, pengertian benda itu diambilkan dari penjelasan Pasal 362 KUHP yaitu segala sesuatu yang berwujud atau tidak berwujud (misal listrik, gas) dan mempunyai nilai di dalam kehidupan ekonomi dari seseorang. ${ }^{3}$

Namun demikian, apa yang dimaksudkan di dalam Kitab Undang-Undang Hukum Pidana mengenai istilah "elektronik" belum dijelaskan secara lebih spesifik. Hal ini mungkin dapat dimaklumi karena pada saat lahirnya KUHP, dunia elektronik masih merupakan hal yang asing pada saat itu. Berkaitan dengan istilah "elektronik" tersebut, maka perlu digali lebih jauh mengenai terminologi dari dua istilah penting yang saling berkaitan yaitu "informasi elektronik" dan "transaksi elektronik". Informasi berasal dari kata Inggris yakni "information" dengan kata dasar "inform" yang secara leksikal artinya "to give, imbue or inspire with some specific quality or character". Jadi informasi bukan hanya sebagai suatu objek ataupun output saja, yang lazim diartikan dalam pengertian bahasa sebagai suatu keterangan ataupun berita, melainkan yang penting terletak pada pemrosesannya dalam arti bahwa informasi dikatakan benar, ada, terjadi, aspek validitasnya terletak bila informasi itu dapat dipertanggungjawabkan secara teknis. ${ }^{4}$ Jadi jelas bahwa informasi itu pada dasarnya tidak hanya dipertanggungjawabkan kebenarannya secara output namun juga secara proses pemberian informasi itu sendiri. Lebih jauh mengenai istilah "Informasi Elektronik" sebagaimana yang diuraikan di dalam Pasal 1 ayat (3) bahwa informasi elektronik adalah satu atau sekumpulan data elektronik, termasuk tetapi tidak terbatas pada tulisan, suara, gambar, peta, rancangan, foto, electronic data interchange (EDI), surat elektronik (electronic mai $)$, telegram, teleks, telecopy atau sejenisnya, huruf,

\footnotetext{
${ }^{2}$ Syafriana,S. (2016). Perlindungan Konsumen Dalam Transaksi Elektronik. Universitas Muhammadiyah Sumatera Utara. h.430.

${ }^{3}$ Hamzah, A.(1987)., Aspek-aspek Pidana di Bidang Komputer. Sinar Grafika. h.30.

${ }^{4}$ Ramli,A.M.dkk. (2007) Menuju Kepastian Hukum di Bidang Informasi dan Transaksi Elektronik. Departemen Komunikasi dan Informatika Republik Indonesia. h.35.
} 
tanda, angka, kode akses, simbol, atau perforasi yang telah diolah yang memiliki arti atau dapat dipahami oleh orang yang mampu memahaminya.

Transaksi elektronik yang sering disebut sebagai "on-line contract" sebenarnya lebih ditujukan dalam lingkup transaksi yang dilakukan secara elektronik. Transaksi elektronik memadukan jaringan sistem informasi berbasiskan komputer (computer based information system), dengan sistem komunikasi yang berdasarkan atas jaringan jasa telekomunikasi (telecommunication based). Transaksi elektronik ini difasilitasi oleh keberadaan jaringan komputer global internet (network of network). Oleh karena itu, esensi dari sistem elektronik sebagai wujud dari konvergensi teknologi informasi, media dan telekomunikasi (telematika) adalah mencakup : keberadaan content dari informasi itu sendiri, computing sebagai sistem informasinya, dan communication sebagai saranan pertukaran informasinya serta community sebagai penggunanya. ${ }^{5}$

Lebih jauh dalam Pasal 1 ayat (2) Undang Undang Nomor 19 Tahun 2016 tentang Perubahan Atas Undang-Undang Nomor 11 Tahun 2008 tentang Informasi dan Transaksi Elektronik, disebutkan bahwa Transaksi Elektronik adalah perbuatan hukum yang dilakukan dengan menggunakan komputer, jaringan komputer, dan/atau media elektronik lainnya. Atas definisi tersebut, maka dapat dikatakan bahwa segala bentuk aktivitas perdagangan yang dilakukan dengan menggunakan media komputer, jaringan komputer dalam hal ini juga bisa diartikan dengan jaringan internet, dan/atau media elektronik lainnya (juga bisa mencakup telepon seluler), merupakan suatu Transaksi Elektronik. Berdasarkan pengertian tersebut, berkaitan dengan hak-hak konsumen yang harus dilindungi pada suatu transaksi elektronik, maka Pasal 383 KUHP menentukan bahwa "Diancam dengan pidana paling lama satu tahun empat bulan, seorang penjual yang berbuat curang terhadap pembeli: (1) karena sengaja menyerahkan barang lain daripada yang ditunjuk untuk dibeli, (2) mengenai jenis keadaan atau banyaknya barang yang diserahkan dengan menggunakan tipu muslihat". Hal ini diuraikan lebih lanjut dalam Pasal 4 Undang-Undang Nomor 8 tahun 1999 tentang Perlindungan Konsumen yang menentukan bahwa Hak konsumen adalah:

a. hak atas kenyamanan, keamanan, dan keselamatan dalam mengkonsumsi barangdan/atau jasa;

b. hak untuk memilih barang dan/atau jasa serta mendapatkan barang dan/atau jasa tersebut sesuai dengan nilai tukar dan kondisi serta jaminan yang dijanjikan;

c. hak atas informasi yang benar, jelas, dan jujur mengenai kondisi dan jaminan barang dan/atau jasa;

d. hak untuk didengar pendapat dan keluhannya atas barang dan/atau jasa yang digunakan;

e. hak untuk mendapatkan advokasi, perlindungan, dan upaya penyelesaian sengketaperlindungan konsumen secara patut;

f. hak untuk mendapat pembinaan dan pendidikan konsumen;

g. hak unduk diperlakukan atau dilayani secara benar dan jujur serta tidak diskriminatif;

h. hak untuk mendapatkan kompensasi, ganti rugi dan/atau penggantian, apabila barang dan/atau jasa yang diterima tidak sesuai dengan perjanjian atau tidak sebagaimana mestinya;

\footnotetext{
${ }^{5}$ Ibid, h.39
} 
i. hak-hak yang diatur dalam ketentuan peraturan perundang-undangan lainnya.

Pemidanaan sebagai ultimum remidium dalam memberikan perlindungan hakhak konsumen, pada praktiknya masih menemui kendala-kendala terutama pada suatu Transaksi Elektronik. Hal ini antara lain dikarenakan oleh beberapa hal:

1. Semakin canggihnya teknologi yang digunakan oleh para pelaku kejahatan dalam mengelabui para korbannya, sehingga hal ini akan menyulitkan aparat penegak hukum dalam menemukan pelaku tindak pidana.

2. Banyak bermunculan modus operandi baru dalam kejahatan yang dilakukan melalui transaksi elektronik.

3. Keterbatasan aparat penegak hukum dalam memantau transaksi elektronik melalui dunia siber yang sangat luas.

4. Terkait Locus Delicti dari pelaku tindak pidana dalam transaksi elektronik.

Aspek Hukum Pidana terkait dengan perlindungan hak-hak konsumen pada suatu Transaksi Elektronik tidak hanya terbatas pada ruang lingkup perlindungan konsumen saja, namun dewasa ini juga telah berkembang pada aspek pidana perbankan. Hal ini dikarenakan aktivitas perbankan merupakan hal yang tidak terpisahkan dari Transaksi Elektronik. Misalnya dalam hal transaksi jual beli secara online, pihak penjual dan pembeli biasanya akan bertransaksi dengan mekanisme transfer melalui ATM, internet banking, mobile banking, kartu kredit, bahkan yang terbaru saat ini telah berkembang sistem uang saku virtual seperti yang telah diterapkan oleh beberapa situs penyedia jasa layanan e-commerce. Saat ini belum ada satu kesepakatan dalam pemakaian istilah mengenai tindak pidana yang perbuatannya merugikan ekonomi keuangan yang berhubungan dengan lembaga perbankan. Ada yang memakai istilah Tindak Pidana perbankan dan ada juga yang memakai istilah Tindak Pidana di bidang perbankan, bahkan ada yang memakai kedua-duanya dengan mendasarkan kepada peraturan yang dilanggarnya. ${ }^{6}$

\subsubsection{Bentuk-Bentuk Tindak Pidana dalam Transaksi Elektronik}

Dalam mengklasifikasikan bentuk-bentuk Tindak Pidana pada Transaksi Elektronik, perlu dilihat aturan pidana yang ada di dalam peraturan perundangundangan, hal ini terkait dengan asas legalitas dalam hukum pidana dimana tidak satupun perbuatan dapat dipidana tanpa ada ketentuan yang mengaturnya.

Pasal 62 Undang - Undang Nomor 8 Tahun 1999 tentang Perlindungan Konsumen Ayat (1)

"Pelaku usaha yang melanggar ketentuan sebagaimana dimaksud dalam Pasal 8, Pasal 9, Pasal 10, Pasal 13 ayat (2), Pasal 15, Pasal 17 ayat (1) huruf a, huruf b, huruf $c$, huruf e, ayat (2) dan Pasal 18 dipidana dengan pidana penjara paling lama 5 (lima) tahun atau pidana denda paling banyak Rp 2.000.000.000,00 (dua milyar rupiah)."

Ayat (2)

"Pelaku usaha yang melanggar ketentuan sebagaimana dimaksud dalam Pasal 11, Pasal 12, Pasal 13 ayat (1), Pasal 14, Pasal 16, dan Pasal 17 ayat (1) huruf d

\footnotetext{
${ }^{6}$ Prasetya,R. (2010). Pembobolan ATM, Tinjauan Hukum Perlindungan Nasabah Korban Kejahatan Perbankan, Prestasi Pustaka. h.106.
} 
dan huruf $f$ dipidana penjara paling lama 2 (dua) tahun atau pidana denda paling banyak Rp 500.000.000,00 (lima ratus juta rupiah)."

Adapun ketentuan yang tidak boleh dilanggar sebagaimana yang dimaksudkan di dalam Pasal 62, di antaranya meliputi:

1. Memproduksi dan atau memperdagangkan barang dan atau jasa yang tidak sesuai baik itu mengenai ukuran, kondisi, mutu, maupun syarat yang harus dipenuhi menurut perundang-undangan.

2. Memberikan informasi yang tidak benar atau menyesatkan konsumen terkait barang dan atau jasa yang diperdagangkan.

3. Menjual barang yang terlarang untuk diperdagangkan.

Pasal 45A Undang Undang Nomor 19 Tahun 2016 tentang Perubahan Atas UndangUndang Nomor 11 Tahun 2008 tentang Informasi dan Transaksi Elektronik

Ayat (1)

"Setiap Orang yang dengan sengaja dan tampa hakmenyebarkan berita bohong dan menyesatkan yangmengakibatkan kerugian konsumen dalamTransaksi Elektronik sebagaimana dimaksud dalamPasal 28 ayat (1) dipidana dengan pidana penjarapaling lama 6 (enam) tahun dan/atau denda palingbanyak Rp1.000.000.000,00 (satu miliar rupiah)."

Berdasarkan rumusan pasal tersebut, perlu ditafsirkan secara lebih jelas mengenai apa yang dimaksud di dalam frasa " menyebarkan berita bohong dan menyesatkan", karena di dalam bagian penjelasan pasal tersebut hanya ditulis "cukup jelas", padahal makna frasa tersebut bisa menimbulkan interpretasi yang multitafsir. Misalkan dalam suatu transaksi elektronik jual beli online si penjual mempromosikan barang dagangannya dengan kata-kata yang menarik untuk memikat calon pembeli, contoh: "Dapatkan handphone menarik dengan harga 1 Rupiah", sedangkan maksud dari si penjual adalah harga 1 rupiah tersebut berlaku untuk pembelian kedua dan dibatasi hanya 10 transaksi pertama, pertanyaana nya adalah apakah promosi yang dilakukan oleh penjual tersebut termasuk ke dalam kategori "menyebarkan berita bohong dan menyesatkan"?

Hal ini menjadi menarik apabila dikaji dari perspektif hukum pidana mengenai unsur pidana yaitu "Actus Reus" atau perbuatan melawan hukum (kejahatan yang dilakukan) dan "Mens Rea" atau sikap batin dari pelaku ketika melakukan suatu tindak pidana.

Dari penjelasan tersebut bisa diambil suatu kesimpulan bahwa mengenai perbuatan " menyebarkan berita bohong dan menyesatkan" perlu dilihat tidak hanya dari perbuatan yang dilakukan, tetapi juga harus dilihat niat dan maksud dari pelakunya. Meskipun demikian, tentu tidaklah mudah mengetahui keadaan batin dari seseorang ketika melakukan kejahatannya dan disinilah diperlukan kejelian dari aparat penegak hukum untuk melihat dari bukti-bukti yang ada untuk merumuskan apakah tindakan tersebut memenuhi unsur pidana.

3.1.2. Modus Operandi Yang Dilakukan Oleh Para Pelaku Kejahatan Dalam Suatu Transaksi Elektronik

Dewasa ini, semakin sering terjadinya kejahatan dalam suatu transaksi elektronik yang menimbulkan kerugian bagi korban, secara tidak langsung telah 
mengindikasikan bahwa modus operandi yang dilancarkan oleh pelaku semakin hari semakin banyak jenisnya dan hal ini yang akhirnya bisa mengelabui para korban dalam suatu transaksi elektronik. Memang masih tersisa satu masalah yang berpangkal pada kenyataan bahwa dunia juridis tidak mengenal masalah perkembangan teknik.

Tantangan bagi para ahli hukum memang bukan tertuju pada pendalaman alatalat teknis. Mereka tidak perlu mendalami alat-alat bantu itu dan memang yang lebih diperlukan adalah materi yang berkenaan dengan hukum (pidana). Para ahli hukum memfokuskan perhatian pada masalah tindakan yang harus diberikan untuk menghadapi pelanggaran-pelanggaran. Jadi hukum, mempunyai akal untuk menghadapi hampir semua kasus hukum seiring dengan perkembangan baru ini. ${ }^{7}$

Perkembangan modus operandi dalam kejahatan transaksi elektronik yang semakin hari semakin mengkhawatirkan, perlu dikenali secara lebih jauh sebagai langkah pencegahan terjadinya kejahatan tersebut. Kejahatan dalam perdagangan secara elektronik (e-commerce), menurut Departemen Komunikasi dan Informatika Republik Indonesia pada umumnya terdiri atas:

a. Penipuan online

Ciri-ciri kejahatan ini adalah harga produk yang banyak diminati sangat rendah, penjual tidak menyediakan nomor telepon, tidak ada respon terhadap pertanyaan melalui e-mail, menjanjikan produk yang sedang tidak tersedia. Risiko terburuk adalah pemenang lelang yang telah mengirimkan cek atau uang atau membayar via credit card tidak memperoleh produk, atau memperoleh produk yang tidak sesuai dengan yang diinginkan atau diiklankan.

b. Penipuan pemasaran berjenjang online

Mempunyai ciri-ciri dengan mencari keuntungan dari merekrut anggota dan menjual produk secara fiktif. Risikonya adalah ternyata sebanyak $98 \%$ investor gagal atau rugi.

c. Penipuan kartu kredit

Pada prakknya, mekanisme transaksi elektronik di Indonesia seringkali menimbulkan kerugian terhadap konsumen. Salah satu bentuk kerugian yang mbul adalah kerugian akibat pembayaran dengan menggunakan kartu kredit yang dilakukan oleh seseorang yang bukan pemiliknya. ${ }^{8}$ Cirinya adalah terjadi biaya misterius pada tagihan kartu kredit untuk produk atau layanan internet yang tidak pernah dipesan oleh pemilik kartu kredit. Risikonya adalah korban bisa perlu waktu yang lama untuk melunasinya. ${ }^{9}$

Beberapa waktu lalu Unit Cyber Crime Subdit II Direktorat Reserse Kriminal Khusus (Dit Reskrimsus) Polda Sulsel berhasil membongkar sindikat penipuan iklan layanan seks online di media sosial. Dari pengungkapan kasus itu, aparat kepolisian menangkap seorang mahasiswi dan rekan pria nya. Kabid Humas Polda Sulsel, Kombes Dicky Sondani dalam keterangan persnya, Senin (15/1/2018), menjelaskan,

\footnotetext{
${ }^{7}$ Smits,J. (1991). Komputer : Suatu Tantangan Baru di Bidang Hukum. Airlangga University Press. h.59.

8 Priowirjanto,E.S. (2014). Pengaturan Transaksi Elektronik dan Pelaksanaannya di Indonesia Dikaitkan dengan Perlindungan E-Konsumen. Padjajaran Jurnal Ilmu Hukum. H.288.

${ }^{9}$ Op.Cit, h.63
} 
kedua tersangka melakukan penipuan dengan modus menjajakan layanan seks online di media sosial. Setelah terjadi kesepakatan pesanan wanita penjaja seks lewat media sosial, kedua tersangka meminta bayaran ditransfer. "Setelah uang ditransfer ke rekening tersangka, akun medsos korban kemudian diblokir agar tidak bisa konfirmasi menghubungi kembali. Intinya ini penipuan modus menjajakan seks online" kedua tersangka dijerat Pasal 28 ayat 1 UU Nomor 19 tahun 2016 tentang perubahan UU No 11 Tahun 2008 tentang Informasi dan Transaksi Elektronik. ${ }^{10}$

\subsubsection{Fungsi Hukum Pidana Dalam Mencegah Dan Memberikan Sanksi Terhadap Kejahatan Dalam Transaksi Elektronik}

Hukum Pidana sebagai hukum sanksi dalam penegakan hukum di masyarakat harus bisa memberikan sanksi yang tegas terhadap segala bentuk kejahatan dalam transaksi elektronik, sehingga dengan sanksi yang tegas itu maka kejahatan dapat dicegah karena adanya suatu efek jera bagi pelakunya. Pertanyaan yang muncul kemudian adalah apakah sanksi secara administrasi maupun secara keperdataan tidak cukup untuk mencegah terjadinya kejahatan dalam transaksi elektronik?

Memang tidak keliru jika mengatakan bahwa sanksi secara perdata maupun administrasi bisa diterapkan dalam hal ini. Hanya, apabila sanksi administrasi dan sanksi perdata ini belum mencukupi untuk mencapai tujuan meluruskan neraca kemasyarakatan, maka baru diadakan juga sanksi pidana sebagai pamungkas (terakhir) atau ultimum remidium.$^{11}$

Dalam mencegah dan memberikan sanksi terhadap pelaku tindak pidana kejahatan di bidang transaksi elektronik, hukum pidana masih menemui beberapa kendala dalam praktek, sehingga hal ini yang menyulitkan dalam penerapannya.

Sebagai contoh, dalam hal kejahatan transaksi elektronik, kapan dilakukannya kejahatan tersebut (berkaitan dengan tempus delicti tindak pidana) dan dimana tempat dilakukannya kejahatan tersebut (berkaitan dengan locus delicti tindak pidana) dapat dimanipulasi bahkan disamarkan oleh pelaku, sehingga hal ini menjadi tantangan tersendiri bagi aparat dalam melakukan penyidikan. Bahkan dalam kejahatan jenis ini, tidak menutup kemungkinan dilakukan oleh pelaku di luar negeri dengan memanfaatkan jaringan internet, hal ini dilakukan oleh pelaku untuk menghilangkan jejak perbuatannya.

Persoalan locus delictie sangat penting untuk menentukan kompetisi relatif peradilan, serta untuk menentukan bekerjanya aturan hukum pidana dari suatu negara, karena masalah tempat ini tidak diatur dalam undang-undang, maka sulit untuk mengetahui hukum pidana mana yang harus diperlakukan kepada orang yang melakukan delik di luar negeri. ${ }^{12}$

Berkaitan dengan persoalan tempus delictie tindak pidana, canggihnya teknologi yang ada pada saat ini sangat memungkinkan untuk mengkaburkan waktu dilakukannya tindak pidana oleh pelaku. Persoalan tempus delictie, hal ini telah diatur

\footnotetext{
${ }^{10}$ https:/ / regional.kompas.com/read/2018/01/15/19085731/penipuan-dengan-modusseks-online-seorang-mahasiswi-ditangkap-polisi

${ }^{11}$ Prodjodikoro,W. (2009). Asas - Asas Hukum Pidana di Indonesia. Refika Aditama h.17

12 Prodjohamidjojo,M. (1997). Memahami Dasar-Dasar Hukum Pidana di Indonesia 1. Pradnya Paramita. h.18.
} 
dalam Pasal 1 KUHP ayat (1) dan ayat (2). Guna menentukan tempus delictie, maka perlu diketahui saat mana yang harus dianggap sebagai saat terjadinya delik. ${ }^{13}$

Para ahli hukum pidana memiliki pandangannya masing-masing dalam memecahkan persoalan tempat dan waktu dilaksanakannya tindak pidana sehingga kemudian menimbulkan persoalan dalam praktiknya mengenai pandangan manakah yang seharusnya dianut, terutama dalam hal kejahatan transaksi elektronik.

Dalam kaitannya dengan yurisdiksi hukum pidana dalam kejahatan transaksi elektronik, untuk penentuan hukum pidana yang berlaku, dikenal beberapa asas hukum pidana sebagaimana yang terdapat di dalam Pasal 2-9 Kitab Undang-Undang Hukum Pidana, yaitu:

1. Asas Teritorial

Yaitu ketentuan pidana dalam perundang-undangan di Indonesia diterapkan bagi seluruh tindak pidana yang dilakukan di wilayah Indonesia, sebagaimana tercantum dalam Pasal 2 KUHP.

2. Asas Nasionalitas Aktif (Asas Personal)

Yaitu ketetentuan pidana dalam perundang-undangan Indonesia diterapkan bagi warga negara yang melakukan tindak pidana di luar wilayah Indonesia, sebagaimana yang termuat di dalam rumusan Pasal 5 KUHP.

3. Asas Nasionalitas Pasif

Yaitu pemberlakuan hukum pidana bagi setiap orang yang melakukan tindak pidana di luar wilayah Indonesia namun merugikan kepentingan nasional, sebagaimana yang termuat di dalam rumusan Pasal 4 KUHP.

Persoalan berikutnya adalah mengenai pa yang digunakan dalam menentukan locus delictie dari suatu kejahatan transaksi elektronik. Ada beberapa pandangan untuk menentukan hal tersebut, di antaranya:

1. Tempat dimana perbuatan dilakukan

2. Tempat dimana alat/media untuk melakukan kejahatan itu berada

3. Tampat dimana pelaku berada

4. Tempat dimana akibat yang ditimbulkan dari kejahatan tersebut terjadi

Maka dari itu, untuk mengatasi persoalan locus delictie dalam suatu kejahatan transaksi elektronik, sudah saatnya diatur secara tegas, sehingga dalam praktik tidak lagi menimbulkan persoalan mengenai tafsiran apakah yang dimaksud dengan tempat dan waktu perbuatan pidana itu adalah tempat dimana akibat dari perbuatan itu terjadi ataukah tempat dimana perbuatan itu dilakukan.

Persoalan yang tidak kalah penting berikutnya adalah mengenai pembuktian. Alat bukti elektronik memang saat ini sudah diakui keabsahannya dalam peraturan perundang - undangan yang ada. Sebagai contoh, dalam Pasal 5 ayat (1) dan ayat (2) UU ITE yang menyebutkan:

(1) Informasi Elektronik dan/atau Dokumen Elektronik dan/atau hasil cetaknya merupakan alat bukti hukum yang sah.

(2) Informasi Elektronik dan/atau Dokumen Elektronik

${ }^{13}$ Ibid. 
dan/atau hasil cetaknya sebagaimana dimaksud pada ayat (1) merupakan perluasan dari alat bukti yang sah sesuai dengan Hukum Acara yang berlaku di Indonesia.

Dengan ketentuan tersebut, maka sudah jelas dan tidak perlu lagi diperdebatkan mengenai keabsahan dari alat bukti elektronik. Namun demikian, yang menjadi persoalan disini adalah mengenai teknis dari pembuktian itu sendiri. Sebagai contoh, dalam kejahatan penipuan kartu kredit, dimana pelaku yang berada di luar negeri dengan menggunakan kecanggihan teknologi bisa menggunakan kartu kredit tersebut tanpa pernah memegangnya secara fisik sehingga menimbulkan kerugian bagi korban yang ada di Indonesia. Persoalannya adalah, bagaimana dapat membuktikan bahwa pelaku lah yang menggunakan kartu kredit tersebut? Disinilah instrumen internasional di bidang kejahatan siber juga diperlukan dalam mengatur hal-hal yang demikian kompleks.

Munculnya bentuk kejahatan baru yang tidak saja bersifat lintas batas (transnasional) tetapi juga berwujud dalam tindakan-tindakan virtual telah menyadarkan masyarakat internasional tentang perlunya perangkat Hukum Internasional baru yang dapat digunakan sebagai kaidah hukum internasional dalam mengatasi kasus-kasus Cybercrime. ${ }^{14}$

Selain itu, persoalan subjek hukum pidana dalam kejahatan jenis ini juga menimbulkan tantangan tersendiri bagi aparat penegak hukum. Biasanya, pelaku kejahatan dalam transaksi elektronik menggunakan media sosial dengan cara membuat akun palsu untuk mengelabui target kejahatan serta menghilangkan jejak digital untuk menyulitkan proses pencarian pelaku. Masalahnya, apakah akun media sosial palsu merupakan subjek hukum pidana?

KUHP kita yang merupakan produk kolonial hanya mengenal manusia atau natuurlijke person sebagai subjek hukum pidana, hal ini dapat dilihat dalam rumusan pasal demi pasal dalam KUHP yang disebutkan dengan kata "barangsiapa". Seiring perkembangan zaman, tidak hanya manusia saja yang dianggap sebagai satu-satunya subjek hukum pidana, melainkan juga badan hukum. Saat ini, dengan perkembangan era digital, dimana manusia tidak hanya hadir secara fisik sebagai manusia namun juga sebagai "subjek" di dunia maya, pertanyaan pentingnya adalah apakah akun media sosial perlu dipandang sebagai subjek hukum yang dapat dijerat dengan sanksi baik secara pidana maupun keperdataan? Hal ini tentu perlu dikaji secara lebih mendalam guna dapat mengakomodir kebutuhan hukum yang ada di masyarakat dengan harapan agar hukum pidana benar-benar dapat berfungsi optimal dalam mencegah dan memberikan sanksi terhadap kejahatan transaksi elektronik.

\section{Kesimpulan}

1. Perkembangan dunia teknologi dan informasi mendorong terjadinya transaksi secara elektronik, namun di sisi lain hal tersebut memberikan celah bagi para pelaku kejahatan untuk melakukan kejahatan dalam suatu transaksi elektronik.

${ }^{14}$ Ramli,A.M. (2004) Cyber Law dan HAKI dalam Sistem Hukum Indonesia. Refika Aditama. h.22 
2. Sanksi secara administrasi maupun keperdataan belum sepenuhnya mampu memberi efek jera bagi pelaku kejahatan transaksi elektronik.

3. Hukum Pidana sebagai ultimum remidium pada prakteknya masih menemui kendala dalam penerapannya khususnya pada kejahatan transaksi elektronik.

\section{Ucapan terima Kasih (Acknowledgments)}

Puji dan syukur saya panjatkan ke hadirat Tuhan YME yang atas kasih dan rahmatNya, saya dapat menyelesaikan penulisan jurnal ini. Terimakasih juga saya sampaikan kepada pihak-pihak yang telah membantu dalam penulisan jurnal ini, khususnya teman-teman dari Fakultas Hukum Universitas Katolik Darma Cendika yang tidak dapat saya sebutkan satu per satu, Bapak Aji Lukman Ibrahim selaku reviewer jurnal esensi hukum, maupun pihak-pihak lainnya yang telah berkontribusi dalam penulisan jurnal ini.

\section{Daftar Pustaka / Daftar Referensi}

\section{Jurnal :}

Priowirjanto, E.S. (2014). Pengaturan Transaksi Elektronik dan Pelaksanaannya di Indonesia Dikaitkan dengan Perlindungan E-Konsumen. Bandung: Padjajaran Jurnal Ilmu Hukum.

Syafriana,S. (2016). Perlindungan Konsumen Dalam Transaksi Elektronik. Medan: Universitas Muhammadiyah Sumatera Utara.

\section{Buku:}

Hamzah,A. (1987). Aspek-aspek Pidana di Bidang Komputer. Jakarta: Sinar Grafika. Marzuki, P.M. (2005). Penelitian Hukum. Jakarta: Kencana.

Prasetya, R. (2010). Pembobolan ATM, Tinjauan Hukum Perlindungan Nasabah Korban Kejahatan Perbankan. Jakarta: Prestasi Pustaka.

Prodjohamidjojo, M. (1997). Memahami Dasar-Dasar Hukum Pidana di Indonesia 1. Jakarta: Pradnya Paramita.

Prodjodikoro, W. (2009). Asas - Asas Hukum Pidana di Indonesia. Bandung: Refika Aditama.

Ramli, A.M. (2004). Cyber Law dan HAKI dalam Sistem Hukum Indonesia. Bandung: Refika Aditama.

Ramli,dkk, A.M. (2007). Menuju Kepastian Hukum di Bidang Informasi dan Transaksi Elektronik. Jakarta: Departemen Komunikasi dan Informatika Republik Indonesia.

Smits, J. (1991). Komputer : Suatu Tantangan Baru di Bidang Hukum. Surabaya: Airlangga University Press.

\section{Online/World Wide Web:}

https:/ / regional.kompas.com/read/2018/01/15/19085731/penipuan-dengan-modusseks-online-seorang-mahasiswi-ditangkap-polisi. (Diakses 20 Agustus 2019). 